\title{
Seroprevalence of hepatitis B and C infection among the HIV-positive population in Abuja, Nigeria
}

\author{
*Tremeau-Bravard A, Ogbukagu IC, Ticao CJ, Abubakar JJ
}

Gede Foundation, 13 Danube Street, Abuja, Nigeria

\begin{abstract}
Background: In Nigeria, it is estimated that 3.6\% of the population were living with Human immunodeficiency virus in 2009, and the country had the world's second highest number of HIV/AIDS related deaths after South Africa. Viral hepatitis is also a major public health concern as hepatitis B virus (HBV) afflicts an estimated 350 million people, and hepatitis $\mathrm{C}$ virus (HCV) affects 150 million people worldwide.

Objectives: We conducted a retrospective study of HBV and HCV seroprevalence among Nigerian population coming to our clinic in Abuja and receiving HIV/AIDS treatment.

Methods: In this cohort study, we collected medical data from 443 HIV-positive patients between September 2010 and May 2011. Standard enzyme immunoassays were used to determine the serological prevalence of hepatitis B ( $\mathrm{HBsAg})$ and $\mathrm{C}$ (anti-HCV antibody) among HIV-positive individuals.

Results: Among the HIV/AIDS positive individuals, we found that 35 patients were infected with hepatitis B virus (7.9\%), 10 with hepatitis $C$ virus $(2.3 \%)$ and 3 with both hepatitis B and $C$ viruses $(0.7 \%)$. The overall hepatitis-HIV prevalence is $10.8 \%$. The majority of the population infected was under 39 years of age $(55 \%)$ and the same proportion of males and females was observed in all the studied categories (HIV, HIV + hepatitis B and/or C). Remarkably, an overall lower CD 4 count was seen in the co-infected population ( 205 cells $/ \mu$ l versus 243 cells $/ \mu \mathrm{l})$, with the lowest seen for the triply infected individuals (97 cells $/ \mu \mathrm{l})$.

Conclusions: Our findings underscore the importance of screening for hepatitis B and hepatitis C viruses in the HIVinfected population in developing countries, and particularly in sub-Saharan Africa, where the epidemics are still growing. Keywords: Human Immunodeficiency Virus, Hepatitis B virus, Hepatitis C virus, cohort study, Nigeria.

African Health Sciences 2012; 12(3): 312 - 317 http://dx.doi.org/10.4314/ahs.v12i3.10
\end{abstract}

\section{Introduction}

According to the World Health Organization (WHO), 33.3 million people were living with Human Immunodeficiency Virus (HIV) in 2009, and a stunning $68 \%$ of them were in sub-Saharan Africa ${ }^{1}$. In Nigeria, it is estimated that $3.6 \%$ of the population were living with the virus in 2009 , and the country had the world's second highest number of HIV/AIDS (Acquired Immune Deficiency Syndrome) related deaths $(220,000)$ after South Africa $^{2}$. Viral hepatitis is also a major public health concern as hepatitis B virus (HBV) afflicts an estimated 350 million people, and hepatitis $C$ virus (HCV) affects 150 million people worldwide ${ }^{3,4}$. Both viruses are endemic in sub-Saharan Africa where an estimated 75 million people (over 35 million in Nigeria) live with hepatitis B and/or C viruses ${ }^{5,6}$.

${ }^{*}$ Corresponding author:
Alexandre Tremeau-Bravard
Gede AIDS \& Infectious Diseases Research
Institute
13 Danube Street
Abuja, Nigeria
Email: a_tremeau_bravard@hotmail.com

312
Since the risk factors for the three viruses overlap, a considerable proportion of patients are infected with multiple viruses. Furthermore, it is known that co-infection increases liver-related morbidity and mortality ${ }^{7}$. To better manage symptoms in this population, a specific combination of active antiretroviral therapy can be helpful. Indeed, chronic hepatitis must be taken into consideration when choosing a drug regimen to treat HIV and hepatitis infections ${ }^{8}$. For these reasons, it is important to know the epidemiology and prevalence of the three viruses, and their effect on the immune system.

A clearer picture of HIV, HBV, and HCV prevalence in Africa is important in order to better educate the population, and control these epidemics. Studies are crucial and necessary to give us a better understanding of the epidemiology of the diseases in developing countries like Nigeria. Therefore, we conducted a retrospective cohort study to investigate the seroprevalence of hepatitis B and C infection in the HIV/AIDS population in our particular setting of the capital of Nigeria, Abuja. We also looked at the impact of the co-infection on the patient CD4

African Health Sciences Vol 12 No 3 September 2012 
count, and at the pattern of presentation of these viruses among the studied population.

\section{Methods}

\section{Study design}

This is a cross-sectional retrospective study among antiretroviral naïve HIV-positive individuals seen at our Gede Foundation clinic in Abuja, Nigeria. Most Gede Foundation patients come for HIV/AIDS related infection. They receive free antiretroviral treatment, through support from the President's Emergency Plan for AIDS Relief program, in accordance with current WHO guidelines?.

HIV/AIDS patients have been coming to our clinic since 2004. We collected the clinical data of regular (old and new) HIV-positive patients, coming for CD4 monitoring, in a Microsoft ${ }^{\circledR}$ Excel database from September 2010 to May 2011. We had a total of 636 entries in the database, and decided to do a retrospective study of the seroprevalence of hepatitis infection among HIV/AIDS patients for 443 of those 636 patients. We excluded 193 patients with incomplete medical records and who were under 18 years old $(n=9)$. Information recorded in the file includes baseline CD4 count, age, sex, and routinely checked hepatitis B/C status. These data were obtained after a one-to-one interview with a professional counselor at the clinic before initiation of antiretroviral therapy. During the interview, patients gave their consent for their data to be used for study purposes. A medical doctor delivered the clinical results to the patient in a private room on site. This study has been conducted in accordance to the Declaration of Helsinki.

\section{HIV serology}

For all serological tests $10 \mathrm{ml}$ of venous blood was drawn from the patient. HIV-1/2 antibodies were detected in the sera of the patients using two distinct immunochromatography capillary assay kits. HIV antibodies were first detected with the Determine ${ }^{\circledR}$ HIV-1/2 (Inverness Medical, USA) kit. All samples reactive to the Determine kit were further tested using the Uni-Gold ${ }^{\mathrm{TM}}$ HIV (Trinity Biotech, Ireland) test kit for confirmation of the presence of antibodies to HIV. Only samples reactive to both Determine and Uni-Gold were considered HIV-positive. HIV status was confirmed by GS-HIV Western blot (BioRad Laboratories, Germany). All the procedures were followed in accordance with the manufacturer's instructions.

\section{HBV and HCV serology}

Hepatitis B and C were detected in the sera of the patients using similar enzyme immunoassays capillary test kits. For HBV, the surface antigen ( $\mathrm{HBs} A g)$ was detected with the Acon ${ }^{\circledR} \mathrm{HBs} A g$ (Acon Laboratories, USA) kit. For HCV, the antibody against HCV (antiHCV) was detected with the Acon ${ }^{\circledR}$ anti-HCV (Acon Laboratories, USA) kit. Reactive tests were repeated at least once to avoid false positive results. The kits were used in accordance with the manufacturer's instructions. All serological tests (HIV and hepatitis) are over $99 \%$ specific and sensitive.

\section{T-Lymphocytes CD4 count}

The T-lymphocytes CD4 count was monitored with a Partec CyFlow ${ }^{\circledR}$ counter (Partec, Germany). Briefly, $20 \mu \mathrm{l}$ of patients' blood was incubated with a fluorescent CD4 monoclonal antibody (Partec CD4 easy count kit), which recognizes the Tlymphocytes CD4 surface antigen. After 15 minutes, the reaction was stopped and the sample was run in the flow cytometer, which gives the CD4 count in cells/ $\mu$ l of blood.

\section{Statistical method}

The data were collected in a Microsoft ${ }^{\circledR}$ Excel spreadsheet, and analyzed with $\mathrm{JMP}^{\circledR}$ Pro analytical software. All count variables were assessed for normality using the Shapiro-Wilk test. All groups showed a non-normal distribution, thus the nonparametric two-sample Wilcoxon rank-sum test was performed for comparison of CD4 and age means. P-values less than 0.05 were considered statistically significant. Statistics were calculated with the 443 cases, and are presented with standard deviations, means, percentages, and p-values in the text and tables of the article. The Likelihood Ratio test was used to assess similarities in the distribution between genders.

\section{Results}

Demographic characteristics of the studied population

A total of 443 patients were included in the study, and among them 244 were women, and 199 men $55 \%$ and $45 \%$, respectively as shown in table 1 . First, we divided the patients in two groups: (1) patients infected with HIV only, and (2) patients co-infected with HIV and HBV and/or HCV. As shown in table 1 below, the majority of patients were between 30 and 39 years of age: they comprised $44 \%$ of HIV mono-infected individuals and $48 \%$ of the co- 
infected patients. The second largest category is the 40 to 49 years of age group. In the HIV group, women outnumbered men ( $56 \%$ versus $44 \%$ ), but for the co-infected population men outnumbered women ( $54 \%$ versus $46 \%$ ), even though more females were included in the study in total $(55 \%$ versus $45 \%$ ). The proportion of male and female is similar between each categories (Likelihood Ratio test, $\mathrm{p}=0.17)$.

Table 1: Demographic characteristics of the studied population

\begin{tabular}{|c|c|c|c|}
\hline Characters & $\begin{array}{l}\text { HIV only } \\
\mathrm{N}=395(\%)\end{array}$ & $\begin{array}{l}\text { HIV/hepatitis } \\
\mathrm{N}=48(\%)\end{array}$ & $\begin{array}{l}\text { Total } \\
\mathrm{N}=443(\%)\end{array}$ \\
\hline \multicolumn{4}{|c|}{ Age group (years) } \\
\hline $20-29$ & $43(11)$ & $3(6)$ & $46(10)$ \\
\hline $30-39$ & 175 (44) & $23(48)$ & $198(45)$ \\
\hline $40-49$ & $120(30.5)$ & $12(25)$ & $132(30)$ \\
\hline $50-59$ & $51(13)$ & $9(19)$ & $60(13.5)$ \\
\hline$>60$ & $6(1.5)$ & $1(2)$ & $7(1.5)$ \\
\hline \multicolumn{4}{|l|}{ Sex } \\
\hline M & $173(44)$ & $26(54)$ & $199(45)$ \\
\hline $\mathrm{F}$ & $222(56)$ & $22(46)$ & $244(55)$ \\
\hline \multicolumn{4}{|c|}{ HIV features } \\
\hline CD4cells $/ \mu \mathrm{l}$ & $243 \pm 197$ & $205 \pm 182$ & $239 \pm 195$ \\
\hline
\end{tabular}

CD4 count is expressed in mean values.

There is no significant difference $(\mathrm{p}=0.12)$ in the mean CD 4 count value between the HIV group (243 cells/ $\mu \mathrm{l})$ and the HIV/hepatitis group (205 cells/ $\mu \mathrm{l})$, even though the count for the co-infected category is lower.
Gender distribution of $\mathrm{HIV} /$ hepatitis coinfection: prevalence, age and clinical features Table 2 shows the prevalence of hepatitis B, hepatitis $\mathrm{C}$ and both hepatitis co-infection along with the mean ages and CD4 count for the HIV-positive population studied. Distribution of the population between men and women is also shown here.

Table 2: Gender distribution of HIV/hepatitis co-infection: prevalence, age and clinical features

\begin{tabular}{|c|c|c|c|c|}
\hline Characters & HIV only & HIV/HBV & HIV/HCV & $\mathrm{HIV} / \mathrm{HBV} / \mathrm{HCV}$ \\
\hline $\bar{N}(\%)$ & 395 & $35(7.9)$ & $10(2.3)$ & $3(0.7)$ \\
\hline M & $173(87)$ & $18(9)$ & $7(3.5)$ & $1(0.5)$ \\
\hline $\mathrm{F}$ & $222(91)$ & $17(7)$ & $3(1.2)$ & $2(0.8)$ \\
\hline Age (years) & $39 \pm 8$ & $39 \pm 5$ & $45 \pm 7^{a}$ & $38 \pm 13$ \\
\hline $\mathrm{M}$ & $43 \pm 8$ & $43 \pm 7$ & $48 \pm 6$ & 53 \\
\hline $\mathrm{F}$ & $36 \pm 7^{b}$ & $34 \pm 6^{b}$ & $37 \pm 4^{\mathrm{b}}$ & $30 \pm 0.7$ \\
\hline CD4cells/ $\mu \mathrm{l}$ & $243 \pm 197$ & $207 \pm 198$ & $232 \pm 143$ & $97 \pm 55$ \\
\hline M & $216 \pm 178$ & $168 \pm 189$ & $285 \pm 142$ & 52 \\
\hline $\mathrm{F}$ & $264 \pm 208^{b}$ & $247 \pm 204$ & $110 \pm 7$ & $119 \pm 56$ \\
\hline
\end{tabular}

CD4 count and age are expressed in mean values.

${ }^{a}$ Wilcoxon rank-sum test, with a statistically significant p-value $(<0.05)$, for comparison between $\mathrm{HIV} /$ hepatitis and HIV population.

bWilcoxon rank-sum test, with a statistically significant p-value $(<0.05)$, for comparison between male and female population

\section{Prevalence}

Among the 443 patients, 35 were HBV-positive, 10 were HCV-positive and 3 had both hepatitis infections. This shows a prevalence of $7.9 \%$ for $\mathrm{HIV} / \mathrm{HBV}$ co-infection, $2.3 \%$ for $\mathrm{HIV} / \mathrm{HCV}$ co- infection, and $0.7 \%$ for $\mathrm{HBV} / \mathrm{HCV} / \mathrm{HIV}$ triple infections. The overall prevalence of HIV/hepatitis co-infection in the studied population is $10.8 \%$. In this study, $87 \%$ of men and $91 \%$ of women are infected with HIV only. The co-infected population 
(HIV and one or two of the studied hepatitis) is distributed as follows: $9 \%$ of men and $7 \%$ of women have hepatitis B, $3.5 \%$ of men and $1.2 \%$ of women have hepatitis C, $0.5 \%$ of men and $0.8 \%$ of women have both hepatitis (HBsAg and Anti-HCV). We noticed that the genders are equally distributed in the four categories (Likelihood Ratio test, $\mathrm{p}=0.32$ ).

\section{Age features}

There are no significant differences in the mean age of the HIV, the HIV/HBV, and the HIV/HBV/ HCV groups ( $p=0.91$ and 0.60 , respectively). The mean age for these groups is 38.7 years. However, patients co-infected with HCV and HIV are significantly older than the other three categories $(\mathrm{p}=0.04)$. Their average age is 45 years old.

The 244 women included in the study have a mean age of 36 years whereas the 199 men studied have a mean age of 43 years (not shown in table). This difference is statistically significant $(\mathrm{p}<0.01)$. This trend is also found if we look at all the categories (HIV or HIV/hepatitis), where all women are under 40 years and all men are above 40 years of mean age (table $2, \mathrm{p}<0.05)$. For instance, women infected with HIV and HBV average 34 years of age while men of the same category average 43 years of age $(\mathrm{p}<0.01)$.

\section{Clinical features}

There are no significant differences in the mean CD4 count of the population infected with HIV alone ( 243 cells/ $\mu$ l), with HIV/HBV (207 cells/ $\mu$ l, p=0.12), with HIV/HCV (232 cells/ $\mu \mathrm{l}, \mathrm{p}=0.87)$ and with the three viruses ( 97 cells $/ \mu l, p=0.14)$. Nonetheless, it is important to note that the HIV/hepatitis infected population shows a lower mean CD4 count than the mono-infected HIV group.

Mean CD4 count was significantly higher for females $(260$ cells $/ \mu l)$ than for males $(213$ cells $/ \mu$ l, $\mathrm{p}=0.01$ ) (not shown in table). Importantly, female patients with HIV only have a significantly higher CD4 count than the males of the same category ( 264 cells $/ \mu \mathrm{l}$ versus 216 cells $/ \mu \mathrm{l}, \mathrm{p}=0.01$ ). The same was true for males and females infected with the three viruses ( 119 cells $/ \mu$ lversus 52 cells $/ \mu l)$. Even though the females with HIV and HBV have a higher mean CD4 count $(247$ cells $/ \mu l)$ than the males $(168$ cells $/ \mu \mathrm{l})$, the difference is not significant $(\mathrm{p}=0.10)$. Noteworthy, among the patients infected with both HIV and HCV, the males have a higher mean CD4 count than the females ( 285 cells/ $\mu$ l versus 110 cells / $\mu \mathrm{l}$ respectively, $\mathrm{p}=0.09)$.

\section{Discussion}

This retrospective study investigated the seroprevalence of hepatitis (B and C) among 443 HIV-positive patients coming to our clinic in Abuja, Nigeria. First, we found that more women than men were infected with HIV only. This gender disparity is consistent with the sex distribution seen in other studies in Nigeria and reflects the national distribution where a little over $55 \%$ of people infected with HIV are women ${ }^{10-13}$. The age distribution in our study does not vary between the HIV and HIV/hepatitis population. Almost half of the studied population is in the 30-39 years age group, which mirrors the overall demographic in Nigeria ${ }^{2}$. However, in our study, more males are co-infected with HIV and hepatitis than females ( $54 \%$ versus $46 \%$, respectively). This distribution has been also found in other parts of Nigeria ${ }^{14-15}$, and could be explained by the fact that the male population is more prone to have multiple sexual partners than females ${ }^{16}$. Interestingly, infected women are 10 years younger than their male counterparts. This significant age difference could reflect the mating pattern of the Nigerian population in general, as this 10-year gap is found in all four categories studied ${ }^{17}$. This age difference could also explain why the CD4 count significantly differs between males and females in this study (213 cells/ $\mu \mathrm{l}$ versus 260 cells $/ \mu \mathrm{l}, \mathrm{p}=0.01$ ). Most importantly, when looking at the mean CD4 count between the HIV only and HIV/hepatitis infected populations, we did not see a significant difference $(\mathrm{p}=0.12)$. This is not surprising, considering that only the triple infection seems to affect the CD4 lymphocyte level in patients ${ }^{14}$.

The co-infection rate of HBV and HIV is relatively high $(7.9 \%)$ in our study, and is comparable to what is found by other investigators in Nigeria ${ }^{18,19}$. It is also important to note that in our study, HBV infection rate is comparable to what is seen in the HIV seronegative population, which indicates an endemic infection by the hepatitis B virus in the Nigerian population ${ }^{18}$. As shown in other studies, the hepatitis B virus infection seems to slightly lower the CD4 count of HIV seropositive patients ${ }^{19,20}$. Here the difference is close to be significant $(\mathrm{p}=0.12)$, so this calls for particular attention from health care providers when treating this patient population. We see that HBV/HIV co-infection affects females and males at the same rate, which is in accordance with a study of 6395 patients in Northern Nigeria where Nwokedi $e t$ al. saw a similar infection rate between 
the two genders in the overall population ${ }^{21}$. This similar gender distribution is seen in all four categories, and demonstrates a relatively consistent studied population.

We found an HCV seroprevalence of 2.3\% among HIV infected patients, which is in concordance with a previous study of 1000 subjects that found an overall prevalence of HCV in $2.9 \%$ of the Nigerian population ${ }^{22}$. Adewole et al. also found a similar rate of $\mathrm{HIV} / \mathrm{HCV}$ co-infection in their study with a prevalence of $2.3 \%{ }^{11}$. This coinfection prevalence is non-negligible, and patients co-infected with these two viruses should receive special care, as it is known that HCV infection causes increased morbidity and mortality in HIV-positive patients ${ }^{23,24}$.

The HIV/HCV/HBV triple infection rate in our study is low $(0.7 \%)$, and reflects what has been found earlier in Nigeria and in other West African countries ${ }^{10,11,25}$. Importantly, this patient category shows a lower mean CD 4 count $(97$ cells $/ \mu 1$, $\mathrm{p}=0.14$ ) than the other categories (HIV or HIV + one hepatitis), confirming other studies' results ${ }^{10,14}$. This shows that co-infection by several viruses affects the patient immune system. Even though only three patients show a triple infection, they must be closely monitored for particular treatment. It would be interesting to conduct a study on a larger triply infected population to see the influence of the three viruses on the CD4 count.

Our study has some limitations. First, in the number of people we included, as more subjects would yield more reliable results. For instance, the triply infected group has few individuals, which could lead to statistical artifacts. Second, even though we double tested hepatitis positive patients, it would have been useful to confirm the presence of the hepatitis viruses with a nucleic acid based technique (such as Polymerase Chain Reaction), as was done for HIV. Nonetheless, our results are consistent with other studies, and are relevant for improving the care of HIV/AIDS patients.

\section{Conclusion}

The overall prevalence of HIV/hepatitis seen here is high $(10.8 \%)$ and should be taken into account by nurses and doctors in clinics when treating HIV/ hepatitis co-infected patients as drug toxicity and interactions can increase morbidity in this population? Finally, the screening of hepatitis B and C should be done on a regular basis among HIV/AIDS patients, as the choice of antiretroviral and drugs used would differ according to the diagnostic outcome ${ }^{26}$.

\section{Acknowledgements}

We want to express our deep gratitude to all patients who participated in this study. We are grateful to Ben Kavoussi (MS), Dr Benoît Menand, Dr Michael Dahmus, Lisa Martinez (RN) and Rhea Fernandez for their critical reading of the manuscript. We would like to thank Dr Andrew Sutherland for his precious help with the statistical analysis.

\section{Conflict of Interest}

The authors have no conflict of interest to declare.

\section{References}

1. WHO-HIV/AIDS [database on the Internet]. World Health Organization. 2011 [cited 2011 Jul]. Available from: http://www.who.int/gho/ hiv/en/.

2. CIA-The World Factbook [database on the Internet]. Washington, DC: Central Intelligence Agency. 2009 [cited 2011 Jul 23]. Available from: https://www. cia.gov/library/publications/theworld-factbook/.

3. WHO-Hepatitis B [database on the Internet]. World Health Organization. 2008 Aug [cited 2011 Jul]. Available from: http://www.who.int/ mediacentre/factsheets/ fs204/en/index.html.

4. WHO-Hepatitis $\mathrm{C}$ [database on the Internet]. World Health Organization. 2011 Jun [cited 2011 Jul]. Available from: http://www.who.int/ mediacentre/factsheets/ fs164/en/index.html.

5. Modi AA, Feld JJ. Viral hepatitis and HIV in Africa. AIDS Rev. 2007 Jan-Mar;9(1):25-39.

6. Madhava V, Burgess C, Drucker E. Epidemiology of chronic hepatitis $C$ virus infection in subSaharan Africa. Lancet Infect Dis. 2002 May;2(5):293-302.

7. Mendes-Correa M, Nunez M. Management of HIV and hepatitis virus coinfection. Expert Opin Pharmacother. 2010 Oct;11(15):2497-2516.

8. Kumar R, Singla V, Kacharya S. Impact and management of hepatitis $\mathrm{B}$ and hepatitis $\mathrm{C}$ virus co-infection in HIV patients. Trop Gastroenterol. 2008 Jul-Sep;29(3):136-147.

9. WHO-Scaling up antiretroviral therapy in resourcelimited settings [database on the Internet]. World Health Organization. 2003 [cited 2011 Oct]. Available from: http://www.who.int/3by5/ publications/documents/arv_guidelines/en. 
10. Otegbayo JA, Taiwo BO, Akingbola TS, Odaibo GN, Adedapo KS, Penugonda S, et al. Prevalence of hepatitis B and C seropositivity in a Nigerian cohort of HIV-infected patients. Ann Hepatol. 2008 Apr-Jun;7(2):152-156.

11. Adewole OO, Anteyi E, Ajuwon Z, Wada I, Elegba F, Ahmed P, et al. Hepatitis B and C virus co-infection in Nigerian patients with HIV infection. J Infect Dev Ctries. 2009;3(5):369-375.

12. Ogbuji QC, Oke AE. Quality of life among persons living with HIV infection in Ibadan, Nigeria. Afr J Med Med Sci. 2010 Jun;39(2):127135.

13. Aliyu MH, Varkey P, Salihu HM, Iliyasu Z, Abubakar IS. The HIV/AIDS epidemic in Nigeria: progress, problems and prospects. Afr J Med Med Sci. 2010 Sep;39(3):233-239.

14. Forbi JC, Gabadi S, Alabi R, Iperepolu HO, Pam $\mathrm{CR}$, Entonu PE, et al. The role of triple infection with hepatitis B virus, hepatitis $C$ virus, and human immunodeficiency virus (HIV) type-1 on CD4+ lymphocyte levels in the highly HIV infected population of North-Central Nigeria. Mem Inst Oswaldo Cruz: 2007 Jun;102(4):535-537.

15. Uneke CJ, Ogbu O, Inyama PU, Anyanwu GI, Njoku MO, Idoko JH. Prevalence of hepatitis$\mathrm{B}$ surface antigen among blood donors and human immunodeficiency virus-infected patients in Jos, Nigeria. Mem Inst Oswaldo Cruz. 2005 Feb;100(1):13-16.

16. Nigeria Common Country Assessment [database on the Internet]. World Health Organization. 2001 [cited 2012 Feb]. Available from: www.ng.undp.org/documents/CCA_2001.pdf.

17. National Population Commission (NPC) and ICF Macro. 2009 Nigeria demographic and health survey 2008: key findings. Calverton, MD: NPC and ICF Macro. [Cited $2011 \mathrm{Jul}$. Available from: www.measuredhs.com/pubs/pdf/SR173/ SR173.pdf.

18. Lesi OA, Kehinde MO, Oguh DN, Amira CO. Hepatitis B and C virus infection in Nigerian patients with HIV/AIDS. Niger Postgrad Med J. 2007 Jun;14(2):129-133.
19. Adesina O, Oladokun A, Akinyemi O, Adedokun B, Awolude O, Odaibo G, et al. Human immuno-deficiency virus and hepatitis $B$ virus coinfection in pregnancy at the University College Hospital, Ibadan. Afr J Med Med Sci. 2010 Dec;39(4):305-310.

20. Idoko J, Meloni S, Muazu M, Nimzing L, Badung B, Hawkins C, et al. Impact of hepatitis B virus infection on human immunodeficiency virus response to antiretroviral therapy in Nigeria. Clin Infect Dis. 2009 Oct 15;49(8):1268-1273.

21. Nwokedi EO, Odimayo MS, Emokpae AM, Yahaya IA, Sadiq MN, Okwori EE. Seroprevalence of hepatitis B surface antigen among patients attending Aminu Kano Teaching Hospital, Kano. Niger J Med. 2010 OctDec;19(4):423-426.

22. Koate BB, Buseri FI, Jeremiah ZA. Seroprevalence of hepatitis $C$ virus among blood donors in Rivers State, Nigeria. Transfus Med. 2005 Oct;15(5):449-451.

23. Monga HK, Rodriguez-Barradas MC, Breaux K, Khattak K, Troisi CL, Velez M, et al. Hepatitis $\mathrm{C}$ virus infection-related morbidity and mortality among patients with human immunodeficiency virus infection. Clin Infect Dis. $2001 \mathrm{Jul}$ 15;33(2):240-247.

24. Chen TY, Ding EL, Seage Iii GR, Kim AY. Metaanalysis: increased mortality associated with hepatitis C in HIV-infected persons is unrelated to HIV disease progression. Clin Infect Dis. 2009 Nov 15;49(10):1605-1615.

25. Diop-Ndiaye H, Toure-Kane C, Etard JF, Lo G, Diaw P, Ngom-Gueye NF, et al. Hepatitis B, $\mathrm{C}$ seroprevalence and delta viruses in HIV-1 Senegalese patients at HAART initiation (retrospective study). J Med Virol. 2008 Aug;80(8):1332-1336.

26. Joshi D, O’Grady J, Dieterich D, Gazzard B, Agarwal K. Increasing burden of liver disease in patients with HIV infection. Lancet. $2011 \mathrm{Apr}$ 2;377(9772):1198-1209. 